\title{
ANTITRUST LAW ENFORCEMENT, PAST AND FUTURE
}

\author{
Thurman Arnold*
}

No government policy has received such long and unquestioned public acceptance as that expressed by the Sherman Antitrust Act. The domination of markets by small groups and the concentration of wealth and power in a few have been a matter of continuing public concern for over half a century. However, in spite of a governmental dogma officially dedicated to the economic independence of individuals, the growth of great organizations in America has been amazing. The Internal Revenue statistics for 1935 show that over $50 \%$ of all net corporate incomes is earned by less than one tenth of $r \%$ of the corporations reporting, and $84 \%$ of the aggregate corporate net profits is earned by less than $4 \%$ of the corporations reporting. We have become a nation of employees. Our private property, our security in our old age and the care of our families when we die usually consist of claims held directly or indirectly against great industrial organizations.

An understanding of the antitrust law problem calls first for a brief introductory statement of the basic economic problem to which the antitrust laws are directed. A second section will indicate why antitrust enforcement has failed in the past. This will be followed by sections discussing the techniques of effective enforcement; what effective enforcement may achieve, with particular reference to the current building investigation; and the new responsibilities cast on the Antitrust Division of the Department of Justice by the outbreak of war in Europe. In a final section there will be presented a plan of organization which should enable the Division to meet both its war-time and peace-time duties with maximum efficiency.

\section{The Basic Economic Problem}

The great mass of our population sell their goods, and services, and labor in the competitive markets. They buy their necessities in a controlled market. Thus our economic structure consists of two separate worlds. The first is a world of organized industry and the second is a world of small unorganized business men, farmers,

- A.B., 19II, Princeton University; LL.B., I914, Harvard University; M.A., I93I, Yale University. Member of the Illinois and Wyoming Bars. Assistant Attorney General of the United States in charge of the Antitrust Division of the United States Department of Justice, since 1938; representative of the Department of Justice on the Temporary National Economic Committee; Professor of Law, Yale University, 1931-1938. Author of The Symbols of Government (1935); (with Fleming James, Jr.) Cases on Trials, Judgments and Appeals (1936); The Folklore of Capitalism (1937); contributor to legal periodicals. 
laborers and consumers. In the first world, there is the power to maintain high prices no matter how much the demand for the product falls off. The result is that production drops, men are laid off and this in turn lowers the purchasing power and makes the demand drop still further. In the second world, unlimited competition still exists and cannot be controlled. In this world live the farmers, retailers, and the small business men who supply the consumers with both goods and labor. Here, when the supply increases or the demand falls off, prices drop to the bottom, but the people go right on producing as much as the conditions of the market will permit. In the first world, we have concentrated control, which makes possible high and rigid prices, which in turn lead to restriction of production and wholesale discharge of labor. In the second world, we find competition, low flexible prices, large production and labor standards often at starvation levels.

The trouble with the system is that the first of these worlds works at cross purposes with the second. In the first world, great organizations keep up prices and lay off labor. The labor so laid off has no power to purchase the consumer goods furnished by the second world.

In the business decline that came in 1937, our troubles were laid to the accumulation of huge inventories which could not be distributed. Industries had speeded up production, enlarged their productive capacity, without any realization that price policies should be inextricably linked with productive capacity. Productive capacity was planned on a ten-year basis. Price policies were planned on a three-months basis. With the expanding market, most industries attempted, by raising their prices, not to distribute the most goods but to obtain the largest share of that expanding purchasing power. The result was that we had become choked with our own wealth. And we have come to realize the absurdity of people going without goods because inventories of these very goods have become too large.

It is my belief that that recent decline is going to have the same effect in making us face the problem of the linking of prices with production and the linking of the problem of industrial organization with distribution that the depression of I933 had in making us face the weaknesses of our financial structure. Forced to act then, we created the SEC which is now accepted as an organization necessary to regulate the marketing of securities. So today we are forced to face the price and distribution problem because the organizing genius of the American people will not tolerate a series of depressions which are caused principally by the fact that we have too much undistributed wealth. I do not believe that the American people will submit to going without goods which they see piled up on every side of them simply because industrial management is unable to distribute the wealth which industrial technicians are able to produce in such quantities. We have the materials, the factories, the men and the money. The problem now is to unleash the productive forces without taking the short and easy road to industrial autocracy.

The ordinary man has little understanding of economic structures. He can only understand what he sees in front of him. When he observes an industrial manage- 
ment which for no understandable reason is unable to distribute the goods which it makes, he turns to new leaders. They at least promise him something and he feels that he has nothing to lose. And preaching and denunciation of totalitarian systems of industrial control is as useless as preaching against disease.

There are of course two ways of running industry to capacity and distributing its product. The one is to establish conditions where competitive independent industries can maintain themselves. The other is for the state to regulate the centralized industrial power which has been allowed to develop. This way is roughly represented by the model of the collective states of Europe in which centralized industry is controlled by the iron hand of government and effective distribution of goods is thus insured. The other path leads to an economy similar to that of Sweden, where government control is limited to the necessities of giving security to independent business.

The inevitable end of industrial control by private combinations, cartels and trade associations is illustrated by Germany today. Prior to the First World War that country had no antitrust law, but industrial self-regimentation was counter-balanced by a strong centralized government, ready to adopt necessary socialistic legislation. In the depression that followed the war, a weak government in Germany permitted the self-regimentation of industries to proceed without restriction. That system of industrial concentration without public responsibility failed disastrously. Public discontent forced the enactment in 1923 of a decree similar in purpose to our antitrust law. But unfortunately for Germany its tradition of free enterprise was too weak. The law was never enforced. The year 1927 witnessed the last gasp of free enterprise in Germany. A Federal Economic Commission was appointed to study the monopoly problem. It sat for three years and produced nearly 40 volumes. The activities of this Commission are interesting because the arguments for the cartel system were identical with the arguments now being used to oppose enforcement of our antitrust laws. First, there was the theory that enforcement of the antitrust laws created uncertainty in business. Then the socialist planners of Germany argued that out of their enforcement no planned economy could result. The trade associations insisted on protection against the chiseler. The unions believed that higher wages would come from large and prosperous cartels. So the Commission ended on the note of letting business combinations alone.

With this encouragement German business regimentation drifted to its logical conclusion. Industrial Germany became an army with a place for everyone and everyone required to keep his place in a trade association or a cartel. Here was arbitrary power without control and regimentation without leadership. That power exercised without public responsibility was constantly squeezing the consumer. There was only one answer. Germany was organized to such an extent that it needed a general and Hitler leaped into power. Had it not been Hitler it would have been someone else.

It is my hope that we are not going to drift through the channels of centralized 
industrial power into the harbor of centralized government control of that power. We have gone far along that road, as the figures below on income testify. There are countless others showing the same tendency. Yet I am convinced that as yet they only represent a tendency which can be cured. They do not yet mean that independent business cannot regain its share in the national income.

With families on the verge of starvation, we have been everywhere confronted with idle machinery and idle labor, because the prices at which goods were sold had no relation to their distribution. This has not been a condition which came upon us suddenly. It had a long progressive development. According to figures prepared by the Brookings Institution, the amount of goods we actually produced from 1922 to 1933 fell short of the amount which we might have produced by an efficient use of our machinery and labor by the colossal sum of 248 billion dollars. There are slightly less than thirty million families in our population. Had we been able to utilize our productive capacity, each of these families could have had eight thousand dollars more in food, clothing, and housing-a sum greater than $87 \%$ of the families in the United States could save in a lifetime.

This is the most dangerous kind of waste, and if it were true that the present efficiency in distributing goods of the present democratic organization of America were the best that independent business could produce, there would be much to be said in favor of regimentation. In times of chaos, military organization is always the easiest way out. An army does not refuse to feed its soldiers, nor does it keep them on a lower level of subsistence than the Commissary and the Quartermasters Corps can afford to furnish. Our present methods are doing that very thing. We have not yet found a way of passing on to the great mass of the public the benefits of modern industrial technique. This is vividly reflected in the income of American families. Eighty-seven percent of our population receives less than $\$ 2500$ a year; sixty-five percent of our families receive less than $\$ 1500$; and eleven million families are fighting starvation: The great mass of people have no security for the future. It is the realization of these hard facts that has made our antitrust policy the most important economic issue before us today. A nation is in danger when the majority of its population has nothing to lose.

But what have the antitrust laws to do with the distribution of goods? Why should a law which has been consistently ignored for half a century suddenly become the center of such intense public concern? The Sherman Act has never before been an important economic factor. Its chief function has consisted not in preserving competition itself but in dramatizing the ideal of competition. Why, then, should it suddenly be forced into the limelight at this particular time?

In the antitrust laws is found the only expression of our competitive ideals which we now have. Just as the Supreme Court represents the ideal of the rule of law, so do the institutions which center around the antitrust laws represent the ideal of a society of independent competing business men and farmers. This is what we call a Democracy. Abandonment of the competitive ideal in favor of a centralized eco- 
nomic structure seems to us to be the abandonment of Democracy. It is my conviction that if we do not center the development of tomorrow around the ideal expressed in the Sherman Act, ineffective though that ideal may have been in the past as a practical agency, the last obstacle to complete industrial autocracy will have disappeared. We will be on our way to an economic organization which follows the line of Germany rather than that of Sweden.

When competition is destroyed there is no alternative except to interfere with and regulate arbitrary power to maintain rigid prices. In other words, monopoly means, sooner or later, government interference in business. I am willing to face that problem when the need arises. Yet it is precisely because I do not wish those areas of necessary interference to increase and because I want to keep the government out of business that I am an advocate of the consistent enforcement of the antitrust laws.

\section{Why Enforcement Has Failed In the Past}

The antitrust laws are the traditional instruments to preserve a competitive economy. They have been on the books almost fifty years, during which they have made business less ruthless and more polite, but they have not stopped the concentration of economic power. The practical question before us is how far they are capable of accomplishing their ends in the future. In order to answer that question, we must diagnose why they have failed in the past.

The answer to that question is far easier than most people imagine. The antitrust laws have not failed. It is the organization provided for their enforcement that has failed. The reason is the simple one that you cannot police a country of one hundred and thirty million people with a corporal's guard. We have tried defining, preaching, denouncing and compromising. We have built up a great system of principles which are supposed to work because of their force as examples and precepts. Indeed, we have tried everything except to get an organization together and do an actual, practical job of policing. Thus we have kept alive the ideal of competition and permitted unrestricted building of industrial empires at the same time.

Let me illustrate the fundamental defects in our enforcement organization by the era of Theodore Roosevelt when trust-busting was supposed to be at its height. To read the history of that time is to get the impression that antitrust enforcement was one of the principal activities of government. How many employees were engaged in it? You will be surprised when I answer that the personnel of the Antitrust Division during that famous crusade consisted of only five lawyers and four stenographers. Follow the enforcement organization of the antitrust laws during the intervening years, years of the greatest industrial growth and economic power which any government has ever known. From I9I4 to I923 there averaged only eighteen attorneys in the Antitrust Division. When the present administration came into office, there were only fifteen. Today, it has been increased to about one hundred and ninety. This small group is supposed not only to police the enforcement of antitrust laws covering the industrial activity of $x 30,000,000$ people; at the same time 
it must handle all legal proceedings connected with thirty-odd other major acts of Congress.

Compare this to other government activities with less comprehensive tasks. The Maritime Commission has a personnel of I,200; the Civil Aeronautic's Authority has 2,800, though the function of neither of these approaches in extent that of the enforcement of the antitrust laws, for which a total personnel of under 400 is available. A closer illustration is that of the Securities and Exchange Commission. It has eight regional offices and a personnel of over 1,200 . If you were to leave all existing securities statutes on the books and take away all of the personnel of that Commission except 400 , its enforcement program which is so widely applauded today would be completely wrecked.

The enforcement of the antitrust laws in the past has been a series of crusades. This is an accurate description. A crusade is concerned more with the dramátization of an ideal than with continuous practical control. So long as the personnel of the Department is so small that violations of the antitrust laws must be ignored, because there is no one to investigate them or try the violators, we have no practical control of the situation. With such an enforcement organization, antitrust cases must be selected on the basis of their relative importance while the vast mine-run of offenders are permitted to go their way unmolested. But to obtain a policing force adequate to accomplish economic results there must be public understanding and support. The antitrust problem must be brought to the public and not reserved for the abstract consideration of the lawyer or the economist.

The questions before the public are these. Shall we continue the policy of easy acquiescence in the enforcement of our antimonopoly policy? Can we content ourselves with the dramatization of the ideal of competition by an occasional case while thousands of offenses are ignored? This has been the policy in the past. Of course, it is better than nothing. While it has not stopped the concentration of power, nevertheless it has saved us from the European cartel system. It has had an important effect upon the ethics of American business by preserving our competitive ideals. All this has been unquestionably worth while. The question which confronts us today is not whether we should abandon the enforcement which we already have, but whether that enforcement is enough.

Let us observe the effects of the failure to provide adequate administrative machinery to enforce the law under the present difficulties which face the Department of Justice. These difficulties fall under two classifications.

First, there is a complaint that the antitrust laws are not clear and that business men do not know how they apply to the particular problem of the industries in which they are engaged. The reason for the absence of a definitely stated antitrust policy in the past, has been due to the confusion about that policy.

One outstanding source of confusion has been the fact that we have considered the intent as more important than the results. This has made it a problem of corporate morality; courts and prosecutors have been busy pursuing that will $o$ ' the 
wisp, corporate intent, while economic results were ignored. The issue has been confused by the notion that we are trying to determine whether great business organizers were bad men or good men. But the trust problem today is not a problem of private morals. It is not a question of the good or bad intention of the monopolist. Whether some of the largest and most exacting monopolies are directed by men with criminal or benevolent intentions is purely a matter of accident. It is the results growing out of their operation of the price and marketing machinery, which are significant for our purposes.

Actually the violation of antitrust laws by great industrial leaders does not usually fall in that class of offenses which involve moral turpitude. It is more like passing through a traffic light at high speed without the intention of harming anyone. This makes it less immoral but not less dangerous. Nevertheless, the predominance of the moral element has thrown a fog over antitrust prosecutions. It has created sympathy because of the predominant achievements of many of the defendants and gives rise to what I call the "put yourself in his place" argument as a human defense. Today we are being accused of lack of gratitude for the benefactions. Obviously, if the Department of Justice were to consider such arguments, however appealing, it would be cast adrift upon a chartless sea of sentiment.

Another source of confusion is the tendency to treat antimonopoly policy as a choice between conflicting general principles. This may be illustrated by the remark of a well-known commentator that behind the Temporary National Economic Committee's investigation lay a conflict between a group seeking to show that bigness in business is bad and a group which seeks to frighten big business into accepting government regulation as a substitute for actual disintegration, the economic planners.

In view of the attitudes in the past it is natural enough to suppose such a conflict exists. Actually, however, there is no conflict between the groups of persons the commentator named nor is there any reason for such a conflict. As a generalization it is as meaningless to say that small units are better than big units as to say that small buildings are better than big ones, or that low buildings are better than high ones.

When applied to concrete situations these metaphysical differences disappear. No governmental group that I know of desires either to break up efficient mass production, or to justify combinations going beyond efficient mass production, which are instruments arbitrarily assessing inflexible prices. The question as to which side of the line any particular industry falls on can be determined not by arguing conflicting principles but by factual investigation. On the facts men might still disagree, but it would not be a disagreement on principle. On the other hand, if an industry has gone so far on the path of monopoly control that competition can never be restored, government regulation is necessary. The question of restoring competition actually is again a judgment on facts and not of conflicting schools of thought.

The second major difficulty which confronts the antitrust enforcing officers is the prevalence of violations by respectable business men. They are often careless and ignorant rather than malicious-the result of long years of sporadic enforcement. 
After a period of fifty years of only occasional enforcement, violations of the antitrust laws have become so common as to cause no comment. Lawyers in many communities have been scarcely aware of their existence. They have not been a problem considered in making business deals. Of course, there has been the chance that the Antitrust Division with its small personnel of men might find time to prosecute. This chance has been as remote as is the chance that a man driving eighty miles an hour along an unpatrolled road will be arrested.

In that state of enforcement of the antitrust laws, coercion and inflexible prices of course have been used as frequently in small businesses as large ones. Small towns, with their agreements between leading grocers and trade associations, built up with biased hopes of cooperation, have been constantly violating the antitrust laws. The process has followed a pattern. The most respectable business men ordinarily withdraw from the meeting so they will not notice what is going on. They should not be criticised for this any more than the president of a university should be criticised for not attacking the athletic administration which somehow or other hires a coach who in turn hires football players.

The competitive struggle without effective antitrust enforcement is like a fight without a referee. In such a contest, the man who puts on brass knuckles will win. This situation will not be solved by hanging mottoes of fair play on the four posts of the ring. The trouble has been that due to inadequate policing, the referee has been absent in most sections of American industry. We should not blame great industrial organizers. In a hard-played game, an aggressive team will go as far as the imposition of penalties permits or else it will lose to the team which does. If a single company in an industry turns buccaneer, self-preservation requires that others follow, in the absence of a referee. This is the necessity of fighting fire with fire. As early as 1921, Mr. Adolph Zukor made a speech in which he predicted the misfortunes which would come from the monopoly control of theaters. He then became one of the leaders in acquiring control of theaters. It is not fair to criticise Mr. Zukor. With the acquiescent policy of the government from I920 to I930, he had to acquire control or someone else would have beat him. We cannot refuse to penalize rough play in the competitive game and then complain because the more gentle team is not successful.

What has happened in this country is that a number of groups have gotten into control of what I have called economic toll bridges which enables them to impose charges on others who have to pass over them to buy or sell their goods. These toll bridges are of many different kinds. Not all of them are illegal, but each of them gives the owner of the toll bridge the power to coerce and to tax others. To give a picture of the problem, I shall list some of the typical practices of the building industries which have been found in recent government proceedings or investigations or are involved in substantial complaints to the Antitrust Division.

- Producers of building materials have fixed prices either by private arrangement or as the principal activity of trade associations. Owners of patents on building 
materials have used them to establish restrictive structures of price control, control of sales methods, and limits upon the quantities sold, in direct contradiction of the broad intent of the patent laws to encourage, through inventions, the development and spread of new productive methods. In some groups the various producers have subscribed to the theory that every member of the industry should have a definite share of whatever business there is to be done, and that no concern should try to get more than its share by price competition.

Various groups of distributors of building materials engage in two kinds of restrictive practices. First, they try to raise the price of their services by establishing a fixed mark-up between the price they pay the manufacturer and the price at which they resell. For this purpose they collusively determine their mark-up or their selling price, and sometimes agree among themselves to boycott manufacturers who will not cut off supplies from price-cutting distributors. Sometimes they conspire with manufacturers' groups to establish a joint price control binding upon the manufacturers' and the distributors' organizations alike.

Contractors who erect buildings add their own systems of restraint. Many contracting groups maintain bid depositories in which copies of all bids and estimates are supposed to be filed prior to the award of the contract. In some of these depositories the bids are opened before the contract is let and the information thus obtained is used to coerce low bidders to withdraw or raise their bids. Other contractor groups maintain central estimating bureaus which calculate the cost of the job and supply the various contractors with the bids they are to make. Some bidding rings determine in advance which contractor is to get the job and arrange their bids so that everyone else bids higher than he. In addition to these efforts to control their charges for services, many of these groups set up little closed markets from which they exclude outside contractors or new types of services.

The building trades unions often participate in these policies of restraint and add new restraints of their own. In recent years they have frequently been used as the strong-arm squads for collusive agreements among contractors, refusing to supply labor where the contractors' ring wishes labor withheld. In other cases the unions themselves have refused to permit the use of new products or new processes because of their fear that the new method might make it possible to erect a house with fewer hours of labor than the old.

Such practices crystallize and lead to legislative restraints on trade. Many building regulations are, in reality, protective tariffs. The licensing and registration of contractors by boards of contractors affords a ready means of discipline over contractors. One statute applies a method of rating bidders according to vague standards interpreted by the contractors themselves. It then puts handicaps on out of the state contractors and out of the state products. This is not an isolated example. Yet on top of such legislative restrictions must be added municipal ordinances designed to restrain competition. They start out from the fact that there must be protection from fire and safeguards of minimum health requirements. They develop into 
legally established boycotts, particularly relating to walls, roofs, electrical work, and plumbing.

Ineffective enforcement of the antitrust laws has led to the development of conditions such as those described above. Confronted by such situations, the Antitrust Division has been compelled to seek methods of enforcement which would be at once effective and constructive.

\section{The Technique of Effective Enforcement}

Most important in the effective, constructive enforcement of the Sherman Act is the application of the Rule of Reason with respect to combinations in restraint of trade. This Rule envisages three situations in which a rigid application of competitive standards is not possible, under the economic necessities of a machine age:

I. Combinations which actually contribute to the efficiency of mass production should not be destroyed.

2. Concerted action on the part of groups of competitors in order to insure orderly marketing conditions should not be considered unreasonable.

3. Where competition has been destroyed mere imposition of penalties does not re-create it. Economic dislocation in great industries must be avoided.

These principles have no meaning except when applied to concrete situations; the reasonableness of combination can not be determined in the abstract. A case by case adjustment between the techniques of mass production on the one hand and free competition on the other is the only method by which reasonable and fair enforcement of the antitrust laws can be effected. Mere imposition of penalties is often insufficient. Where the facts of any industrial situation make a particular combination reasonable, the civil procedure should be used as a means of settling the question and to give business men a guide. This is not a regulation of what business must do, but a clarification of what business may do. The great advantage of applying the Rule of Reason is that it allows us to take up one problem at a time in the light of its particular facts. This is the only way of avoiding the pitfalls of general regulation and permanent social planning.

This case method of developing and clarifying the law is in accordance with our judicial tradition. It has peculiar utility with respect to the Sherman Act because in interpreting that act in a particular case there must be an exercise of judgment after factual investigation on at least one of two questions. The first is this: Does a particular organization go beyond the necessity of efficient mass production and become an instrument of arbitrary price control? The second question is: Does a particular combination of organizations or individuals tend to create orderly marketing conditions, or is it an instrument to maintain rigid prices or to coerce competitors? The answers to these questions for the benefit of American industries must follow factual investigations of each industry, and will only be obtained by presenting the facts to the courts in a number of different cases to develop our activity. Therefore, the clarification of the law is inextricably bound up with the efficient prosecution of 
a great many cases, not a selected few. The thousands of price fixing agreements and instances of coercion of small businesses which are now unprosecuted are gradually changing this country into an industrial autocracy. Attempts to clarify the law in the abstract while violations go uncurbed are useless.

The case by case clarification of the law also points the way to legislative improvements. If I am correct in my belief that blanket amendments to the Sherman Act would be valueless, and perhaps dangerous, then it is the only intelligible guidepost for Congress.

An essential complement to the case method of clarifying the law is the use of public statements, to explain the decisions and attitudes of the Department of Justice in the selection and prosecution of each case.

This policy was officially announced by Attorney General Cummings on May I8, I938:

The aim of these statements in connection with any particular proceeding or investigation is to serve ( $\mathrm{I}$ ) as a guide to businessmen who seek information on the probable action of this Department in similar circumstances; (2) to aid the Department itself in formulating a consistent policy of antitrust law enforcement; (3) to serve as a warning to those engaged in similar illegal practices; and (4) to call the attention of the Congress to the interpretation and application of antitrust laws by the Attorney General, as they may have a bearing upon contemplated legislation. ...

In general, the statements will cover ( $\mathrm{I}$ ) the conditions which the Department believes to exist in the particular industry which create monopolistic control or restraint of trade; (2) the reason why the particular procedure was followed, whether a civil suit, consent decree, criminal prosecution, acceptance of pleas of nolo contendere, or dismissal of the proceeding; and (3) the economic results which are to be expected from its action in the particular case.

With present personnel, there is no way that I know of to avoid the use of discretion and judgment in the conduct of the Antitrust Division. All complaints can not be prosecuted. A selection must be made. Therefore, the grounds underlying that selection should be publicly stated in each case to the end that a consistent and open policy of prosecution may gradually be derived from statements in connection with individual cases.

In the past there has been no continuing practice of announcing at the initiation of each prosecution why that particular prosecution was brought. The complaint itself, directed at the narrow issue of the case, is not a sufficient guide because legal strategy necessarily plays a large part in its draftsmanship. It is a well-known fact that business men have always found difficulty in interpreting the policy of the Department of Justice. The need for information on its policy is evidenced by the countless memoranda which are submitted to the Department in the hope of getting some indication of the Department's attitude. The rulings of no other department can give that information, because it is what the Department of Justice is going to do and not what other departments think which is important to business men.

There is no reason why information as to the policies of the Department of 
Justice, so long as it does not involve the granting of individual immunity, should not be available to businessmen. The distribution of that information may be of advantage to both sides. So far as the Government is concerned, it should prevent the argument of acquiescence in the cases where the Government has not actually prosecuted. So far as business is concerned, it should be both a warning and a guide, because it localizes the Department's interpretation of the law to a particular industry. Obviously, however, it is unsafe to convey that information by quasipromises of immunity to individuals on the bases of the data which they submit. The first step by a large organization in a plan of monopoly control is often the first move in a chess game and the player on the opposing side can not possibly guess the strategy behind it. There is no way of telling whether or not the particular data submitted is a Trojan horse.

By prefacing each important suit with a statement of policy there can' be built up gradually within the Department a reasonably consistent policy which would be a matter of public record. More consistency in the changing personnel of the Department might be expected to follow because it is a habit of human institutions to follow a pattern which they have publicly accepted. If changes were made, cogent reasons would have to be developed. If the policy was wrong it could be corrected. This seems to me to be the only solution to the problem of bringing what has been a concealed process of the necessary selection of cases out into the open where it can be a guide and a warning.

The question of procedure, the choice in a given situation, once court proceedings have been decided upon, of the appropriate available weapon, is covered in another paper in this symposium, and I shall touch on it only briefly.

As a deterrent, criminal prosecution is the only effective instrument under existing statutes. It may well be that if the Department had the subpoena power it would be an effective substitute for the grand jury. It may also be that if there were teeth in the civil remedy, it might be a deterrent. But for this purpose the civil injunction is little more than a form of unemployment relief for lawyers since it carries no penalties.

The civil suit has a useful place as a supplement to the criminal proceedingnot as a substitute. It is in the constructive application of the antitrust laws to situations where some sort of combination or concerted action is necessary that the constant use of civil procedure is most important. It was the lack of understanding of the constructive use of the antitrust laws which led to the impression that the Sherman Act was passed to commemorate Sherman's march to the sea. It is most important, if we are to have any widespread and effective enforcement of the antitrust laws, that it be understood that they are not a mere destructive agency, that they need not be used to destroy efficiency or create serious economic dislocations.

The concurrent use of civil and. criminal procedure is not found in connection with ordinary criminal laws. In some concurrent proceedings, where the final outcome of the criminal case is uncertain and relief to competitors and to the public is 
even more important than punishment of offenders delayed by long trials and appeals, the consent decree may be the best solution. It is the position of the Department that it was the intention of Congress in providing these two concurrent penalties that they could be used. In spite of the confusion recently created, the law on this point is, I think, clear. I know of no ethical policy which contradicts the plain provisions of the act of Congress or which forbids criminal prosecutions while negotiations for the consent decree are pending. However, the test of a consent decree obtained under such circumstances must be relief to the public which would be denied by delay. It should not be on the basis on which private litigation is compromised. One is concerned with the past; the other with the future.

Whatever the legal remedy invoked, the first requirement for efficient prosecution is to proceed against every combination which is blocking the distribution of a product from the raw material to the consumer. Combinations exist at every stage of the industrial process. An aggressive combination compels others to combine in defense. Indeed it is often as difficult to find out who is the moral culprit as to define the term "aggressor" in international law. One frequently finds business men in an industry who are unable to survive without following established practices which are in violation of the law. Within a single industrial field, to attack one of a series of combinations and leave others alone is simply to give an advantage to those who do not happen to be investigated. We must take such related combinations up all at once if we are to produce economically desirable results.

We have done this in milk; we have done it in fertilizer. But perhaps the best example is an industrial problem which is in the forefront of all other industrial problems. A house is the product of a tangle of goods and services. No one who furnishes any single element which goes into the completed product can greatly raise or lower the cost of the whole product. Neither a single heavy industry, nor the distributors of its products, nor the contractors who install them, nor the labor which works on them, operating alone, can by vigorously competing do anything more than handicap themselves for the advantage of others. Like a number of dogs who have hold of the same piece of meat, none of them dares drop it because he would lose out completely. This is an analysis by way of figure of speech. Suppose we make it more concrete. It means that no major economic purpose can be attained by pursuing a labor union in Los Angeles, a group of contractors in Chicago, and a heavy industry in New York for antitrust violations in the building field. Of course it is our duty to prosecute complaints, and isolated prosecutions may protect particular competitors from injury. But the economic results in housing can only be accomplished by prosecuting on a nation-wide scale, and simultaneously, the various combinations which are creating the log jam in the building industry.

\section{What ÉfFective Enforcement Can Do}

The Antitrust Division's ihtvestigation of the building industry is just reaching the prosecution stage, yet already evidence is rapidly accumulating which shows 
what may be accomplished when there is an attempt to investigate and prosecute on a nation-wide scale all the illegal restraints existing in a particular industry, from the producer to the ultimate consumer. Congress had provided funds which made available 80 men for the investigation. We made preliminary surveys in 26 cities. Limited personnel and travel funds compelled us to postpone more intensive investigation in half of these cities. Grand jury proceedings have been instituted in many of them and now indictments are beginning to be returned.

Our experiences in this building investigation have resulted in several discoveries which make it useful as a pattern for an extension of this type of activity to the problem of the distribution of other products to the ultimate consumer. We have discovered that vigorous investigation brings results beyond the actual cases that are prosecuted. These results spring from a realization by those engaged in the industry that an actual hazard exists if they violate the law. In investigating the building trades we are not dealing primarily with the criminal class of our population. We are dealing with ordinary law-abiding citizens who are caught in a vicious system which they are incapable of overturning without the aid of the Government. The presence in a city of an organization engaged in antitrust investigational work gives to those law-abiding elements in an industry an assurance that they will not be forced into illegal practices through the necessity of protecting themselves against the unlawful aggressions of others, or through fear of retaliation. The presence of our investigators, therefore, in and of itself, has been sufficient to stop illegal practices. In one city, for example, since our investigation began, lumber prices have dropped $18 \%$ and sand and gravel prices have declined $22 \%$. The low bid on a large electrical contract which was readvertised was $21 \%$ under the previous low bid.

A second discovery we have made is that when there is an honest effort to prosecute impartially every unreasonable restraint affecting building costs, whether it comes from manufacturers, contractors, or labor, most of the criticism and misunderstanding as to our purposes disappear and we get adequate public support. The public understands the reasons for our action in the building industry. They have been brought down from the realm of abstract law. I do not know of a single city in which our building investigation has been carried on that public support has not been forthcoming.

A third discovery is that a staff in the field equipped to investigate thoroughly the complaints in a given locality, obtains an amazing amount of voluntary assistance from groups who otherwise might not have taken the initiative to complain. A display of activity invariably causes businessmen and consumers who have been the victims of improper practices to take heart and offer their active cooperation. In one large city, for example, there were a number of bid depositories operating in a way which we considered to be in restraint of trade. The members of these depositories were interviewed by our investigators. In a short time everyone of them informed us that he was ceasing the practice we were investigating. This was done before we had developed any case against them. They told us they were doing it because they 
believed that if other unlawful restraints were cleared away from the building industry they would be better off without these depositories. Although it would be unfair to announce publicly the names of the individuals concerned or the city where this happened, I think I can safely say that this is typical of what is happening in many places.

A fourth discovery is that these results will not be permanent, in building or any other industry, if the staff is withdrawn. If we were to withdraw our investigators from any locality where we have already accomplished beneficial results, it is almost certain that within a year the old abuses would reappear. As we have often asserted, the problem is similar to that of controlling traffic. There must be a traffic policeman on a crowded corner. If the policeman is there the law will be obeyed. If we have an adequate staff in the field to receive and investigate complaints we will get the complaints and the investigations will accomplish beneficial results. If the men are not there, nothing will happen and the consumers will get discouraged and the law will be ignored. It is this fact which gives special importance to the plan of organization presented in the concluding section of this article.

\section{The War-Time Responsibilities of the Antitrust Division}

Before I attempt to outline this plan of organization, I wish to show how war had added to the task of the Antitrust Division. This is essential, for the outbreak of war in Europe was immediately followed in this country by an outbreak of funeral orations over antitrust enforcement. All those who love a military organization in society announced that it was time to ignore the antitrust laws.

A neutral nation in time of war faces two economic problems of major importance. The first is the long-range problem of preventing the dislocation of our economy by war boom industries. The second is the immediate and constantly recurring problem of profiteering.

The first problem may be described as that of keeping our economy from being distorted by the other fellow's war. As a neutral nation we may expect a rush of capital to invest in industries which furnish supplies to belligerents. From that we may expect staple industries to be put at a disadvantage as they were in the last war. We all recall the inflation during our neutrality in the First World War, which robbed productive industry for war boom industry, resulting in complete unbalance of prices. We were confronted with the spectacle of the southern farmer going hat in hand to the newly created millionaires and asking them for charity's sake to buy a bale of cotton. In the last war we did not anticipate this problem. There were, therefore, no controls and no attempts at control. Real wages went down one third while thousands of new fortunes were made. Thus was an economy built up which depended on the perpetuation of the war to prevent its utter collapse.

There is no reason inherent in our economy to go through this experience again. We have such a surplus today of idle capital and productive capacity that there is no reason why staple enterprises should be starved. They need not be starved if we 
can prevent them from being put at a disadvantage. It may be, of course, that some sort of government encouragement needs to be given to specific industries. If so, it is first important that such needs be studied case by case. Secondly, it is important that government subsidies or other encouragement should not be superimposed upon a structure so rigid and inelastic that these subsidies will have the effect of raising prices instead of lowering them.

We are still suffering from the effects of the housing shortage of the last war, during which activity in the housing field practically ceased. A further cessation of construction activity will result in a housing shortage of unprecedented severity. Such capital as now stands ready for investment in housing can easily be discouraged by high construction costs, when it is presented with the attractive picture of great profits in war industries. Thus we will be paving the way to another post war economic collapse in the future while we are depriving ourselves of needed dwellings today.

The housing industry offers the greatest opportunity of non-war industry to prevent an economic unbalance. It is imperative that we do not allow a new housing shortage to be superimposed on the one which we now have. Therefore, speaking strictly for the present, we need houses for their own sake. We also need to build them to provide an industrial balance wheel for the troubled times ahead. In such a situation it becomes the clear duty of the Antitrust Division to investigate and attack all of the restraints which handicap construction.

I have referred to the building industry as a concrete example of the long-range problem of the prevention of economic dislocation during a time of war. Other industries present different problems. The antitrust law is our only flexible instrument by which we can solve such problems, not through broad government regulation, but by the case by case method under common law.

The second problem of a neutral nation in time of war is usually called profiteering. With the outbreak of war came a sudden and unjustified rise in prices of food. During this rise the Antitrust Division found itself on the front line. For the first three weeks of the war we were receiving complaints from all parts of the country at a rate which at times reached 250 a day. They were coming in so fast that it was impossible to answer them promptly, let alone investigate them. They came from farmers' associations, trade unions, businessmen's groups, women's clubs, state and federal officials, members of Congress, retailers, manufacturers, wholesalers, and unemployed persons. The great majority of them appeared to be from responsible sources. Few of them were of a character that could be lightly dismissed.

Here is the kind of situation that needs immediate action, not long-time reform. It is an advance symptom of what may happen in the future. The Antitrust Division is in the front line not only because it is the first agency to receive complaints from businessmen and consumers, but because its remedies are in line with our free and independent economy.

What was the cause of the sudden price raise which occurred at the outbreak of 
this most recent war? It owed its start, of course, to public hysteria. It owed its continuance to the highly organized character of our agencies for the distribution of goods. Everyone today belongs to a trade association, or to a fair trade committee, or to a chamber of commerce. Food distributors meet regularly. They know the prices that are being charged by their competitors. Statistical information is broadcast as to those prices. Nothing is more natural than that such associations should take advantage of a situation which leads to quick temporary profits.

Therefore, war brings to the task of the Department of Justice the necessity of checking the possible tendency of current associations and organizations dealing with production and distribution to take advantage of situations where profiteering is possible. This must be done without destroying the legitimate practices of these organizations. The line between the legitimate and illegitimate use of such associations depends on the facts in the particular cases.

To function satisfactorily in peace-time or war-time, we must have sufficient personnel for continuous investigation. The antitrust law is a flexible instrument in that it follows the common law technique of taking up one thing at a time. By this method of taking up one case at a time broad general regulation becomes less necessary. Thus it is that a vigorous antitrust policy in time of war will make active price control more limited in its application. Antitrust enforcement in the beginning may be the ounce of prevention which will be worth the pound of cure.

\section{A Plan of Organization to Meet War-Time and Peace-Time Needs}

The experience gained in the building investigation, coupled with that obtained in the months during which the Temporary National Economic Committee has been sitting, provides the basis for a plan of organization which would permit the Antitrust Division to cope with its rapidly expanding war-time duties and which would also furnish far more effective peace-time machinery for enforcing the antitrust laws than has heretofore existed. I have recently presented our desired program at hearings before the Temporary National Economic Committee. So far as the Antitrust Division's participation is concerned, the plan requires two things:

I. An adequate prosecuting group sufficient to break up the organizations imposing restraints, which can be withdrawn after the prosecutions are over; and,

2. One or two men assigned permanently in each state to preserve the gains by hearing complaints and keeping in close contact with the situation.

A large permanent staff in the field is not necessary. One or two men located in the larger cities to receive complaints and make investigations would be sufficient, if the public knows that we have men in reserve who can be called out in the event a local situation gets out of control. The men permanently allocated to each state could act as a clearing house for consumer information and complaints. With such an organization we could change what is now an unorganized protest into an intelligently organized enforcement movement. With various existing consumer groups, such as farmers, consumer associations, trade associations, women's clubs, state and 
federal officials, retailers, manufacturers, wholesalers, and unemployed persons disseminating information gathered by the resident field staff, profiteering would become unprofitable.

The members of the permanent field staff would not have control over policy, but they would refer all important questions of policy to the Antitrust Division for decision. The Antitrust Division would then make one of the following dispositions of each complaint referred:

(a) Clear violations of law would be referred to a grand jury for such action as seemed warranted.

(b) Where further development of the facts seems necessary and cannot be obtained by field investigations, the grand jury should be used to get additional facts. Such use of the sitting grand jury to obtain information is often in itself a most effective method of enforcement. The grand jury should be used as a real investigating device and not alone as a means of obtaining indictments. There should be no hesitancy to recommend that no true bills should be returned where such result is indicated as proper by the facts.

(c) Conditions which have created the complaint should be discussed wherever possible with the business organization concerned, with a view to removing the source of the complaints.

(d) Complaints involving intrastate commerce should be referred to the appropriate local officials and at all times the local representative of the Antitrust Division should be in touch with the state enforcement agents so that cooperation between federal and state governments is always consistent and coordinated.

In addition to this enlargement of the staff of the Antitrust Division, there is need for a' body that can hear cases involving situations in which the antitrust laws appear to be inadequate for such treatment as the facts require. Business should be provided with at least an opportunity to present its contentions before a regularly organized committee with experience in monopoly problems whenever it feels that the existing law prevents efficient operation. And what is true of businessmen is true of consumers also. Such a tribunal with power to investigate facts and make recommendations to Congress in specific cases could exist anywhere in the Government. Nevertheless, it seems to me obvious that the present Temporary National Economic Committee has already established an organization which would be admirable for that purpose. It is the only committee on which there are representatives not only of the Senate and the House but also of executive branches of the Government. It has already developed experience and technique in hearings on problems of particular industries.

I would suggest, therefore, that a sufficient appropriation be provided to allow this committee to continue as a tribunal to hear and investigate facts regarding any particular industries which have difficulty operating under present laws and in connection with an antitrust enforcement program. It should be announced that this is the proper tribunal before which to present matters where hearings are sought not strictly pertaining to law violations, and also when it is desired to have consideration given to amending present laws to deal with particular industrial problems. 
The total annual appropriation for all these activities for the Antitrust Division and the Temporary National Economic Committee as a permanent body would not exceed two million dollars. That sum, of course, is in addition to the present appropriation allocated to the Antitrust Division. We are about to spend nearly two billion dollars a year on armaments alone. The type of organization outlined herein would permit effective control within reasonable limits of prices, and save millions annually to consumers. Moreover, it is most important that wherever government subsidies are granted to any industry, the industry be cleared of the restraints which prevent experimental competitive development and increased volume so that these subsidies will not be the means of establishing even more firmly in power aggressive organizations with arbitrary control of prices. Government spending without antitrust enforcement is simply the distribution of bonuses to a favored few.

A permanent organization capable of enforcing the antitrust laws through the cooperation and understanding of business, labor, agricultural organizations and consumer will provide an even, steady, fair and consistent application of their principles in cooperation with private organizations. Such an organization will reestablish consumer sovereignty in this country. It will give the rank and file of the members of every industry the benefits that can come from freedom of independent enterprise. It will give the rank and file of labor protection from exploitation by small groups who do not have the interests of labor at heart and develop, case by case, the freedom of labor to organize for legitimate labor disputes.

The Sherman Act is America's contribution to economic legislation. The question before the American people is whether they want to save their competitive system. If so, it will not be done by attacking the morals of the businessmen who have been thrown into a "free for all" fight without enough referees present at the battles. It will be done only if an enforcement organization is built up, with regional offices and a personnel sufficient to investigate and prosecute all violations instead of some of them. 